\title{
ОТРАЖЕНИЕ ЭКОЛОГИЧЕСКОЙ \\ ПРОБЛЕМАТИКИ В СЕМИОТИКЕ ДОКУМЕНТАЛЬНОГО КИНО OT NATIONAL GEOGRAPHIC MAGAZINE
}

\author{
Пикулина Софья Максимовна \\ студент \\ Научный руководитель: Березнякова Клавдия Сергеевна \\ старший преподаватель кафедры \\ массовых коммуникаций ГИ НГУ \\ ФГБОУ ВПО «Новосибирский национальный \\ исследовательский государственный университет»
}

\begin{abstract}
Аннотация: в статье рассматриваются способы, тенденции, приемы и техники отражения экологической проблематики документальных фильмов на официальном Youtube-канале National Geographic Magazine. Выявить это позволяет семиотический анализ, покадровый знаковый анализ (на иконы, индексы и символы) каждого фильма, поэпизодный анализ, анализ синтактики, семантики и прагматики. Мы отбирали каждый четвертый короткометражный фильм (маркировка «Short Film Showcase») на канале про экологическую проблематику. Структурно-семиотический подход к исследованию документального кинематографа позволяет выявить, как данная проблематика освещается в медиапространстве, какие техники для донесения смысла до зрителя используются, как подается материал об одной из самых актуальных проблем современности через киноязык.
\end{abstract}

Ключевые слова: семиотика, семиотический анализ, экологическая проблематика, National Geographic Magazine, документальный фильм.

\section{REFLECTION OF ENVIRONMENTAL ISSUES IN THE SEMIOTICS OF DOCUMENTARY FILMS FROM NATIONAL GEOGRAPHIC MAGAZINE}

\section{Pikulina Sofya Maksimovna Berezniakova Claudia Sergeevna}

\begin{abstract}
: the article discusses the ways, trends, techniques and techniques of reflecting the environmental issues of documentaries on the official Youtube-channel of National Geographic Magazine. Semiotic analysis,


frame-by-frame sign analysis (for icons, indexes and symbols) of each film, episode analysis, analysis of syntactics, semantics and pragmatics allows to reveal this. We selected every fourth short film (labeled "Short Film Showcase") on the channel about environmental issues. The structural-semiotic approach to the study of documentary cinema makes it possible to identify how this issue is covered in the media space, which techniques are used to convey meaning to the viewer, how material is presented about one of the most pressing problems of our time through the film language.

Key words: semiotics, semiotic analysis, environmental issues, National Geographic Magazine, documentary.

От знания экологической культуры зависит будущее человека. К сожалению, документальные фильмы на данную тематику (как срез реальности) в основном дают негативную оценку. Разобьем анализируемые нами 13 фильмов по тематическим блокам. Всего получилось 8:

1. Люди-герои, пожертвовавшие большую часть своей жизни ради спасения флоры или фауны.

2. Наблюдение за жизнью вымирающих животных и защита их от браконьеров.

3. Вторая жизнь старых вещей, «reuse».

4. Природа, которая может быть опасна (экологические бедствия).

5. Люди, которые поставлены в тяжелое положение из-за природных, климатических изменений.

6. Необратимые природные изменения.

7. Люди, нашедшие выход из опасной экологической ситуации действие «win-win» - польза и для человека, и для природы.

8. Борьба людей с загрязнениями, особенно с пластиком.

Еще Ю. Хабермас [1, с. 33] приводил причины изменившегося отношения человека к природе и, как следствие, ухудшения экологической обстановки. Так, человек теперь воспринимает окружающий мир не как «партнера», а как «средство» для достижения своих целей. Такое отношение дает все больше тем для экологической журналистики и документалистики, науки и искусства. Изменения в лучшую сторону могут быть возможны лишь тогда, когда каждый осознает свою личную ответственность за происходящее. 
Кино - это сообщение от создателей, адресованное зрителям, наполненное идеологическими, социальными и культурными кодами, которые представляют собой соотношение означаемого и означающего, систему ожиданий вероятного и невероятного [2, с. 95]. Как минимальную единицу анализа мы взяли эпизод, так как кадры лишь в соединении друг с другом имеют коммуникативную и семантическую ценность. В эпизодах мы вычленяли главенствующие символы, иконы или индексы. Следует отметить, что лишь те знаки, которые вносят конкретизацию или глубину, а не просто копируют реальность, имеют важное значение для исследования. При подсчете всех знаков после знакового анализа мы выяснили, что индексов 365 , икон - 234, символов - 84 .

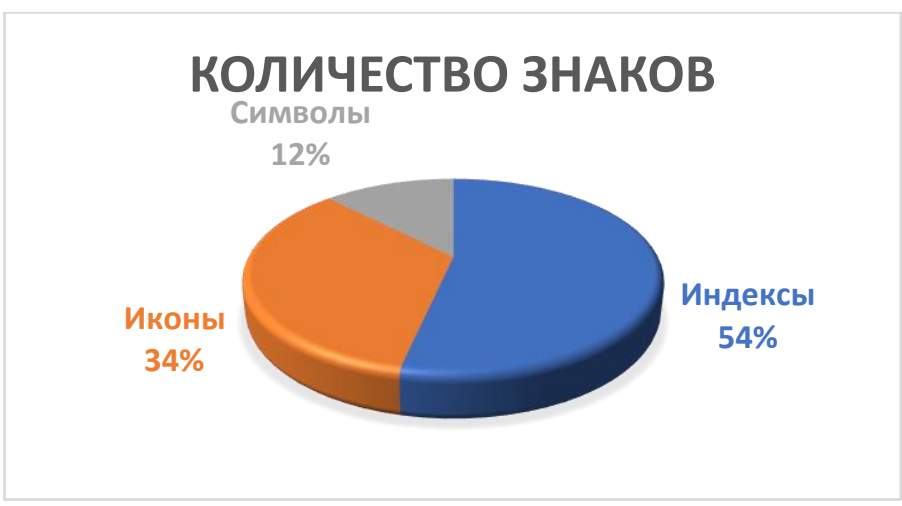

Рис. 1. Процентное соотношение знаков

Индексов оказалось больше всего, потому что, во-первых, в смысловом и визуальном построении кадра всегда будут акценты, индексы всегда указывают на главную идею кадра; во-вторых, индекс не допускает «конфликта ожиданий»; в-третьих, индекс передает факт, что наиболее ценно для референтивного документального кино (значение же символов понятно только при общем коде). Кроме того, используя анализ знаков и синтагматические отношения, визуальные и аудиальные приемы смены эпизодов, тематические блоки, мы раскрыли другие ракурсы кинозначения и выделили, а также описали эпизоды. Приведем один пример поэпизодного разбора второго фильма - «Capturing Endangered Frog's Song». В нем мы нашли два эпизода, не считая пролога и эпилога:

- Пролог начинается кадрами леса и заканчивается кадрами лягушекэндемиков. Здесь ключевой знак - икона. С ее помощью в кадрах визуально отображаются звуки дикой природы - мы видим части спектрографического 
анализа, колебания звуковых волн. Звук становится не просто дополнением, а целым денотатом.

1) Первый эпизод начинается планом ученых в экспедиции и резкой сменой тональности музыки на яркую и веселую; и заканчивается планом одним из видов исчезающих лягушек. Ученые говорят здесь о важности поддержания биосистемы, о звуке как ключе к диалогу и помощнику ответа на вопрос: «Как мы можем помочь исчезающим видам лягушек?» Лягушки здесь представлены «экстенсионально» [3, с. 242] - несколько видов редких лягушек как один для изучения объект. Главный знак здесь - индекс получения звуков природы и конкретно звуков диких лягушек, особенно «Plectrohyla exquisita». Интерпретанта показывает нам старания поиска звуков учеными во всех возможных средах — и в воздухе, и на земле, и под водой. Кадры здесь показывают в основном референтивную функцию по У. Эко [4, с. 80]: отображение действительности, будней экспедиции, взятий анализов и поиска звуков. И это характерно для всего фильма, не только для первого эпизода — символов здесь почти нет.

2) Второй эпизод начинается кадрами перехода человека через реку и сменой музыки на воодушевляющий эмбиент, заканчивается же он интервью с ученым. Здесь повествуется о сложности экспедиции вообще, но о радости за наличие такого инструмента - спектрографического анализа звуков. Здесь лидирует индекс пути и индекс воодушевления от результатов. Смысловые ожидания зрителя оправдываются - ученые действительно находят тот редкий вид лягушек «Plectrohyla exquisita», который они искали, и вычленяют ее звук под водой из общего природного потока шумов.

- Эпилог начинается кадрами диких животных в лесу и яркой музыкой; заканчивается затемнением. Здесь подводятся итоги - запись семи разных видов лягушек, изучение биосистемы в целом, чтобы знать, как поддержать естественные условия существования животных и не дать им исчезнуть с планеты окончательно. Индексы впечатления и радости от найденных результатов - здесь самые явные.

Такой анализ дал нам понимание самых важных и лидирующих знаков, мотивов, техник и приемов, что позволило приблизиться к ответу на исследовательский вопрос: «как отражается экологическая проблематика в документальных фильмах от National Geographic Magazine, на основе полученной информации из знакового, семиотического анализа?» Чтобы полностью сформулировать на него ответ, понадобилось также 
проанализировать синтактику, семантику и прагматику 13 фильмов. Однако важно понимать, что полисемия характерна для кинематографа, а потому множественные интерпретации - это его обыденность. Кроме того, перцептивные, когнитивные и идеологические коннотации всегда связаны с конкретным культурно-историческим контекстом [5, с. 242], а потому конкретное значение всегда будет результатом определенных реалий интерпретатора. Утверждать единственную трактовку семантики и прагматики невозможно, поэтому мы даем трактовку вероятную.

Так, самое частое отношение среди знаков (синтактика) - это подобие, основанное на противопоставлении - «сгущение», метафора по К. Метцу [6, с. 210]. В основном это проявляется относительно главного героя: например, икона переходящего реку орангутанга перемежается с иконой переходящего реку человека («А Rare Look at the Secret Life of Orangutans»), икона дерущихся диких животных предшествует иконе мужественных и храбрых женщин в военной форме («Meet the World's First All-Female Team Created to Combat Poaching») и др. Контраст знаков очень силен, он расширяет ассоциативное поле и встречается чаще всего при изображении человека, сталкивающегося с природными бедствиями, например индекс добычи песка из Камбоджи соседствует с индексом строящегося нового острова в Сингапуре («How Sand Mining Destroys One Home to Build Another»). Синтактика референтивна - денотаты указывают на реальные объекты: загрязнение пластиком, браконьерство, вырубка лесов, нехватка ресурсов. И здесь также лежит объяснение, почему в фильмах меньше всего символов, но больше всего индексов - документалистика стремится передать факты действительности, опираясь на самые характерные их признаки и сигналы.

Семантика достаточно антропоцентрична — в означаемом встречаем экологические катастрофы и необходимость их решения, в означающем видим этот смысл сквозь призму человека и его жизни. Человеческая культура:

1) разрушается из-за исчезновения места (вырубка лесов, импорт чрезмерного количества песка) — в фильмах «How Sustainable Plantations Help Save Uganda’s Decimated Forests», «How Sand Mining Destroys One Home to Build Another»;

2) страдает от нехватки определенной еды (из-за загрязнения моря, из-за чрезмерной ловли рыбы, из-за глобального потепления и т.д.) и теряет экономическую стабильность, так как моряки, фермеры и люди, 
занимающиеся традиционным хозяйством, находятся на грани разорения - в фильмах «See How Fishermen Are Working Together to Protect These Lagoons», «Coffee Farmers Hopeful For Their Dying Crops»;

3) боится, что следующее поколение, их дети, вместо красивого разнообразия природы, животных и растений, увидит безжизненные пустыни - в фильмах «Care About the Ocean? Think Twice About Your Coffee Lid», «Capturing Endangered Frog’s Song», «One Woman's Remarkable Journey to Protect Lions», «See What It Takes to Hide a Secret Tracker in a Rhino Horn», «Meet the World's First All-Female Team Created to Combat Poaching», «Can Cell Phones Help Save Rain Forests? This Tribe Thinks So»;

4) опасается дальнейшего загрязнения окружающей среды, которое оказывает прямое негативное воздействие на здоровье человека - в фильмах «A Boat Made From Plastic Waste is One of Kenya's Solutions to a Global Problem», «Care About the Ocean? Think Twice About Your Coffee Lid»;

5) не хочет, чтобы нарушение биома сказалось на их семейных делах, жизни, бизнесе; чтобы происходила конфронтация с природой — в фильме «Researching How to Live With Coyotes».

Знаки-доминанты всегда относятся к полю «человек», семантика здесь консервирует и закрепляет данные значения.

В прагматике мы выделили самый яркий знак - индекс грусти и печали, разочарования и утраты. Например, в фильме «See How Fishermen Are Working Together to Protect These Lagoons» лидирует индекс злости, отчаяния и печали, так как чрезмерная ловля морских животных, загрязнение моря, глобальное потепление уничтожают морскую экосистему. Это, определенно, эмотивный знак. Его другой вариант - индекс радости и успеха научного достижения или же открытия, например, в фильме «A Boat Made From Plastic Waste is One of Kenya's Solutions to a Global Problem» множество индексов радости от процесса вторичного использования пластика, от красоты переработки, радость от процесса создания материальных объектов, от удачного нахождения решения проблемы загрязнения пластиком всех природных сред. Эти два противоположные, на первый взгляд, индекса имеют общую цель - отображение важности происходящего для самого человека, а также стремление к идентификации зрителя и героя через ощущение личной истории. Из-за принципа зеркальности интерпретатор чувствует то же самое, и общий код помогает достичь задумки фильма. 
Знаковый и поэпизодный анализ, анализ синтактики, семантики и прагматики позволили нам выявить основные тенденции отображения экологической проблематики через призму семиотики. Кратко опишем их.

1) «Миссийность» - герои воспринимают свою роль по спасению каких-либо животных или территорий как свою миссию, как цель всей своей жизни. Особенно ярко это заметно в фильмах «How Sustainable Plantations Help Save Uganda's Decimated Forests» и «Researching How to Live With Coyotes»;

2) Мысли о будущем и детях - эмотивные сообщения направлены на вызов сочувствия и переживания, какой же мир останется детям. Такая мысль часто звучит в киноязыке фильмов, и наиболее яркие примеры - это «See What It Takes to Hide a Secret Tracker in a Rhino Horn» и «Meet the World's First All-Female Team Created to Combat Poaching».

3) Трагедийность - кинематографические и не кинематографические коды показывают серьезный ущерб и губительное влияние на природу человека. Индексы переживания, иконы свалок, иконы рыб в пластике - все показывает масштабность событий. Интерпретанта призывает действовать как можно скорее для решения экологических проблем. Особенно ярко это видно в фильмах «Care About the Ocean? Think Twice About Your Coffee Lid» и «A Boat Made From Plastic Waste is One of Kenya's Solutions to a Global Problem».

4) Воинственность, противостояние - темы «врага», икона оружия и военной формы, индекс армейских подразделений и т.д. - иногда люди не видят другого решения проблемы, кроме как угрозы. Однако даже в поведении персонажей и на уровне коннотаций можно обнаружить решительность, властность и мотив сражения, например, в фильмах «Meet the World's First All-Female Team Created to Combat Poaching» и «Can Cell Phones Help Save Rain Forests? This Tribe Thinks So».

5) Жертвенность - особенно часто это фигурирует относительно женщины, так как из-за распространённости патриархальной идеологии в традиционных обществах (которые чаще всего страдают из-за экологических проблем), на женщину накладывается больше социальных ожиданий и норм. Например, она жертвует семьей и родственными связями, высмеивается за свою причастность к научному сообществу, не видится месяцами с ребенком - по синтагматическим цепям в фильме «One Woman's Remarkable Journey to Protect Lions» становится ясно, насколько многим героиня готова 
пожертвовать ради своего вклада в сохранение окружающей среды через работу в заповеднике. Герои могут так же жертвовать своим сном, здоровьем (иконы долгих ночевок в палатке, иконы долгого пути, индексы усталости), например, в фильме «A Rare Look at the Secret Life of Orangutans».

6) Зависимость состояния культуры от экологических проблем - если исчезает земля (из-за загрязнения и отравления среды, из-за разрушения экосистемы и т.д.), то пропадает и культура, на ней взращённая. Изображение таких культур «на грани» часто очень эмотивно, содержит множество индексов грусти, слез, потери. Ярчайшие примеры - фильмы «How Sand Mining Destroys One Home to Build Another» и «Can Cell Phones Help Save Rain Forests? This Tribe Thinks So».

7) Масштабность - показанная проблема чаще всего не локальна, но интернациональна. Икона роющихся детей на свалках, индекс включенности каждого слоя населения в решение экологических проблем, кинотекст об общечеловеческом значении действий героев - все говорит о том, что проблемы экологической направленности едины для всех, а десигнат общемировой. Например, в фильмах «A Boat Made From Plastic Waste is One of Kenya's Solutions to a Global Problem» и «See How Fishermen Are Working Together to Protect These Lagoons» наиболее впечатляющие семы масштабности.

8) Антропоцентричность - модальность «разговора о самом себе», даже когда речь идет про природу, лидирует в экологическом дискурсе. Эта перцептивная установка может помочь достичь большей идентификации интерпретатора с героем и на основе печальной судьбы конкретных людей вызвать интерпретанту необходимости действий для спасения планеты. Нарратив об экологических проблемах по отношению их влияния на человеческую деятельность особенно силен в фильмах «Care About the Ocean? Think Twice About Your Coffee Lid» и «A Rare Look at the Secret Life of Orangutans».

9) Тема «маленького человека» - акцент на беспомощности героя, столкнувшегося лицом к лицу с масштабной проблемой, не способного ее решить в одиночку; обычный человек, чаще всего из страны третьего мира, не в состоянии решить проблему «врага» в лице правительства или добывающих корпораций. Традиционные ценности семьи и тихого благополучия сталкиваются с жаждой наживы на природных ресурсах, истребления экосистемы ради получения нужных материалов или же с природными, стихийными бедствиями. Наиболее сильно это видно в фильмах «How Sand 
Mining Destroys One Home to Build Another» и «Coffee Farmers Hopeful For Their Dying Crops».

10) Близость природы и человека - мысль о том, что человек связан с природой, очень символична, так как она помогает интерпретатору ассоциировать себя с планетой, что вызывает желание помочь решить экологические проблемы. Это встречается как на уровне кинотекста, так и на уровне визуальных фигур. Яркие примеры: фильмы «Capturing Endangered Frog's Song» и «A Rare Look at the Secret Life of Orangutans».

Таким образом, репрезентация мира из документальных фильмов экологической тематики может помочь зрителям осознать важность проблем, разрушающих не только экосистему планеты, но и жизнь простых людей. Вызванная интерпретанта может создавать реальные действия. Чем чаще в инфополе мы слышим негативные новости о состоянии экологии, тем больше подобных фильмов в нашем медиаполе должно быть - пока не поздно, человечеству необходимо осознать прямую зависимость благополучия его жизни от благополучия окружающей среды. Визуальная семиотика, знаковый анализ, анализ эпизодов, синтактики, семантики, прагматики помогает понять, как такие фильмы сконструированы, какие техники, приемы, тенденции они используют, чтобы донести свою репрезентацию мира для зрителя.

\section{Список литературы}

1. Хабермас Ю.: Техника и наука как идеология. - М.: Праксис, 2007. $-208 \mathrm{c}$.

2. Барт Р. Избранные работы. Семиотика. Поэтика. - М.: Прогресс, 1994. - $325 \mathrm{c}$.

3. Эко У. Отсутствующая структура. Введение в семиологию. - М.: Издательство «Симпозиум», 2006. - 548 с.

4. Пирс Ч.С. Начала прагматизма. Т. 2 (Логические основания теории знаков). - СПб.: Лаборатория метафизических исследований философского факультета СПбГУ; Алетейя, 2000. — 352 с.

5. Березнякова К.С., Некрасов В.Д. Семиотический метод и метод языкового поля как способы интерпретации фотопроектов (на материале творчества В. Кламма и Ф. Тёлкова) // Вестник Новосибирского государственного университета. Серия: История. Филология. - 2020 г., № 6. - C. $239-249$.

6. Метц К. Воображаемое означающее. Психоанализ и кино. - СПб.: Издательство Европейского университета в Санкт-Петербурге, 2013. - 334 с. 